\title{
Evaluating the effect of the modified atmosphere, chitosan coating, and packaging on qualitative properties of okra during storage
}

\author{
A. Heydarian ${ }^{1}$, E. Ahmadi ${ }^{1}$ and F. Dashti ${ }^{2}$ \\ ${ }^{1}$ Department of Biosystems Engineering, Faculty of Agriculture, Bu-Ali Sina University, Hamedan, Iran \\ ${ }^{2}$ Department of Horticultural Science, Faculty of Agriculture, Bu-Ali Sina University, Hamedan, Iran
}

\begin{abstract}
Summary
Providing fresh vegetables and fruit to the consumers and maintaining their shelf life are among the most important post-harvest measurements. In the present research, the effect of three types of packaging films, atmosphere modified by $5 \% \mathrm{O}_{2}+10 \% \mathrm{CO}_{2}+$ $85 \% \mathrm{~N}_{2}$, chitosan coating, and two temperature levels of 25 and $4{ }^{\circ} \mathrm{C}$ on the shelf life of okra during 12 days of storage is evaluated. Afterward, the effect of these treatments on the weight loss percentage, the mechanical properties (breaking force $\left(\mathrm{F}_{\mathrm{brek}}\right)$, penetration force $\left(F_{\text {max }}\right)$, elasticity modulus $\left.\left(E_{\text {mod }}\right)\right)$, color indices of $L^{*}, a^{*}, b^{*}$, color difference $(\Delta E)$, and gas variations gas inside the packages is investigated using completely randomized design with three replicates. The results of variance analysis showed that the effect of gas composition, packaging film, coating, and temperature on some measured factors were statistically significant at $1 \%$ or $5 \%$ probability levels. Samples stored in silicon nano-emulsion films at $4^{\circ} \mathrm{C}$ due to the slowdown metabolic activities and chitosan coating due to controlling the respiration rate showed the best quality during storage time. Tissue firmness decreased during the shelf life, but these changes were less in nano-emulsion film samples than in the other two films. The variation of $b^{*}$ component and color difference was less in nano-emulsion film samples. Finally, the results indicated that the use of modified atmosphere technology, chitosan coating, and packaging films were effective in maintaining the quality of okra and increasing its storage period.
\end{abstract}

Keywords

modified atmosphere, chitosan, nano packaging film, okra, storage

\section{Introduction}

The quick deterioration of fruit and vegetables has led the researchers to find a solution to increase the shelf life of the yields (Petropoulos et al., 2018; Hosain et al., 2010). The foodstuff packaging is a vital technology to maintain the freshness, prevent the deterioration, physiological and mechanical damages, and increase the shelf life of the fresh products. Employing various post-harvest technologies prevent the light, heat, and humidity transmission and control the microorganism activity, thereby reducing the cost and maintaining the quality of fresh and processed products

\section{Significance of this study}

What is already known on this subject?

- There is no research in this regard on okra during storage.

\section{What are the new findings?}

- The storage life of okra pods is very short. The aim of the present study is to evaluate the effect of packaging films and chitosan coating under modified atmosphere storage condition on qualitative and quantitative parameters of okra during storage.

What is the expected impact on horticulture?

- The results of this investigation indicated that the employing of silicon nano emulsion film with chitosan coating under atmosphere conditions is useful for maintaining the quality properties of fruit and improving the shelf life, which is important in terms of marketability.

during storage (Antala et al., 2014). Okra grows in tropical and subtropical areas, it is rich in protein, carbohydrate, and vitamins, and plays an important role in the human diet (Gemede et al., 2015). In addition, okra contains a significant amount of oil and protein and its necessary and unnecessary amino acids can be compared with those of soya (Farinde et al., 2007). Fresh okra has a shelf life of 10 days and is stored at $1-10^{\circ} \mathrm{C}$ due to high respiration rate and moisture loss (Hong et al., 2012). Today, the use of nanotechnology in the packaging industry is developed and expanded. One of the desirable effects of nanotechnology is to improve the quality of different products in terms of foodstuff safety, quality control, etc. (Dimitrijevic et al., 2015). Nanotechnology has been proposed as one of the most promising strategies to improve the overall properties of food packaging materials, thus extending the shelf life of packaged food (Uysal Unalan et al., 2014). The increasing use of nanoparticles in the production of food and agricultural nanocomposite packages is important because it not only reduces environmental problems but also improves the performance of these materials during the storage time (Taghizadeh et al., 2010). The aim of the packaging is to increase the shelf life and prevent the bacterial and shipping damages, as well as control the humidity and gases transmission, thereby reducing food spoilage (Rossi et al., 2017; Wyser et al., 2016). Modified atmospheric packaging (MAP) is one of the famous methods for increasing the shelf life of fresh products in which the aging process is reduced by increasing $\mathrm{CO}_{2}$ and decreasing $\mathrm{O}_{2}$ (Rai et al., 
2002). Decreasing the respiration rate, producing ethylene, and metabolic reactions in the modified atmosphere lead to a reduction in product deterioration. Moreover, many studies reported that MAP maintains the physical, biochemical, and sensory characteristics of the fruit (Li et al., 2011; Giacalone and Chiabrando, 2013). In MAP technology, the atmospheric condition around the fruit, microbial growth rate, deterioration and water loss of the product is reduced. According to the studies, in a closed atmosphere, a reduction in $\mathrm{O}_{2}$ and an increase in $\mathrm{CO}_{2}$ concentration reduce the deterioration of okra, avocado and grapefruit, apricots, peaches, and pears (Janick, 1993). The maintenance with the controlled atmosphere leads to a decrease in the rate of chemical and biochemical reactions, as well as the reduction of growth of pathogenic microorganisms which, in turn, cause maintaining quality and extending storage life of products (Gholami et al., 2017). The use of coatings and edible films are being increased in order to maintain the sensitive features like flavors, fragrances, and the appearance of different products and increase the shelf time of fruits and vegetables (Hassan et al., 2018).

Chitosan edible coating is a non-fragrance and non-flavor polysaccharide with a high molecular weight that is widely used because of its antifungal, biological and biochemical properties (Viswanath et al., 2018). Chitosan is a natural polymer obtained from chitin, which is abundantly found in crustacean shells (Liu et al., 2019). Chitosan is considered as a good barrier to oxygen gas due to its semi-permeability and relative permeability to water vapor in food packaging. (Sandhya, 2010) evaluated the effect of MPA on different fruit and vegetables and indicated that 1 to $5 \%$ of $\mathrm{O}_{2}$ in MPA was suitable for maintaining the safety and quality of the products. In addition, numerous pieces of research have reported that MPA leads to reducing the damages and maintaining the quality of avocado (Sivankalyani et al., 2015), cucumber (Manjunatha and Anurag, 2014), and carrot (Leceta et al., 2015). Al-Naamani et al. (2018) used nano composite zinc oxide-chitosan coatings on low-density polyethylene (LDPE) films for extending the storage life of okra and reported its positive effect on maintaining the humidity and preventing the growth of bacteria and fungi during storage. Finger et al. (2008) evaluated the effect of temperature, and polyvinyl chloride packaging film (PVC) on storage life of okra and reported that the low temperatures $\left(5-10^{\circ} \mathrm{C}\right)$ compared to high temperature $\left(25^{\circ} \mathrm{C}\right)$ resulted in controlling and decreasing the weight loss and maintaining the humidity of the product in PVC film. (Jiang et al., 2013) investigated the microbial changes and post-harvest properties of chitosan coating treated mushroom. The results indicated that in chitosancoated samples, respiration rate and amount of microorganisms were respectively increased and decreased and their firmness was almost stable. The storage life of okra pods is very short. Hence study of application of growth regulators to extend shelf life of okra is the need of the day. After harvest, the fresh produce undergoes several physiological changes including weight loss due to water evaporation, decay, microbial infection and compositional changes. Modified atmosphere packaging (MAP) is one of the food processing technologies that can extend the shelf lives of many foods. Nitrogen $\left(\mathrm{N}_{2}\right)$, oxygen $\left(\mathrm{O}_{2}\right)$ and carbon dioxide $\left(\mathrm{CO}_{2}\right)$ are used extensively to modify atmospheric gas compositions. The aim of the present study is to evaluate the effect of packaging films and chitosan coating under modified atmosphere storage condition on qualitative and quantitative parameters of okra during storage.

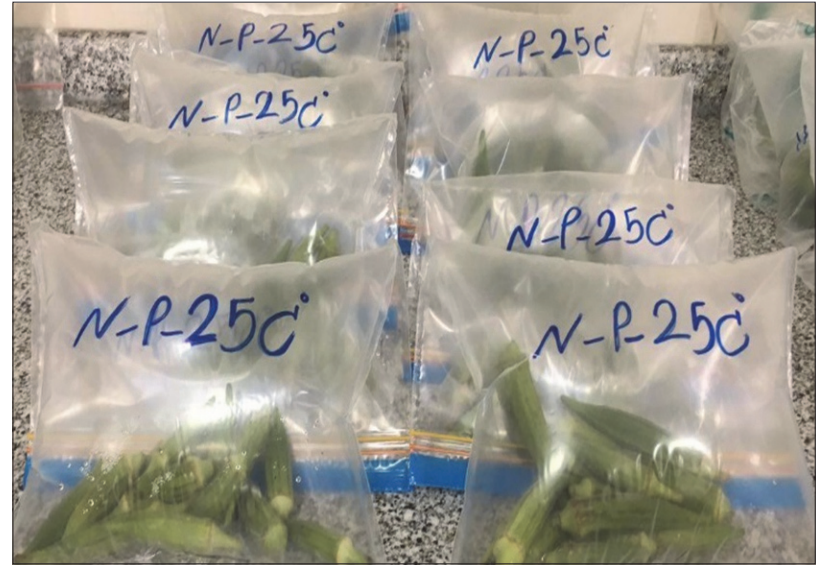

FIGURE 1. Okra packaging prepared under the MAP.

\section{Materials and methods}

The process of the present research was being performed in Laboratory of Mechanical Properties and Rheology of the Biosystems Engineering Department, Faculty of Agriculture, Bu-Ali Sina University, Hamedan, in 2016. Okra cv. 'Kano Dwarf' was selected due to its short post-harvest life and provided from farms in Kermanshah Province. Okras were handpicked, they were free of any spots, contamination, decay, with almost the same size and shape, without any mechanical and microbial damage. The treatments of the present study was chitosan covering, modified atmosphere by gas mixture of $5 \% \mathrm{O}_{2}+10 \% \mathrm{CO}_{2}+85 \% \mathrm{~N}_{2}$, three types of packaging films including silicone nano emulsion (Nano Bespar Aytak Co.), nano-polyethylene, and light polyethylene (LFO200), as well as two temperature levels of $1 \pm 4^{\circ} \mathrm{C}$ (refrigerator) and $1 \pm 25^{\circ} \mathrm{C}$ (room temperature). The first, a solution of $1 \%$ chitosan, was prepared by dissolving $5 \mathrm{~g}$ of chitosan powder in distilled water plus acetic acid at a $\mathrm{pH}=4$.

The coating was done through soaking method for $1 \mathrm{~min}$ and the samples were allowed to dry for 2 hours under normal environmental conditions. Finally, both coated and normal samples (approximately $100 \mathrm{~g}$ ) were put in silicone nano emulsion, nano polyethylene, and light polyethylene (LFO200) packaging films. Then the air inside the packages was sucked and the gas mixture was injected into them. Next, after heat-sealing, the packages were stored in an environ-

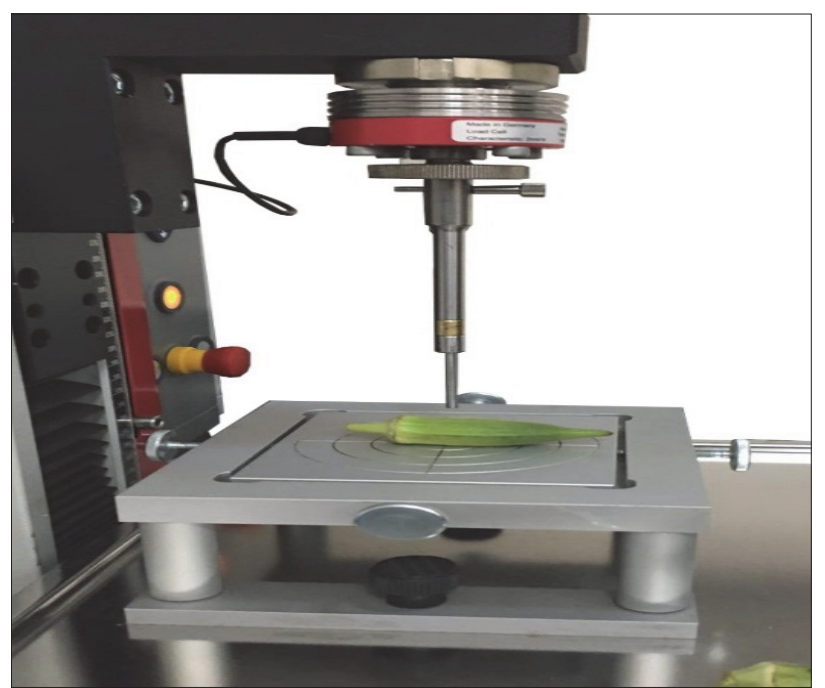

Figure 2. Zwick/Roell Model BT1_FR0.5TH.D14: Puncher test on the okra. 


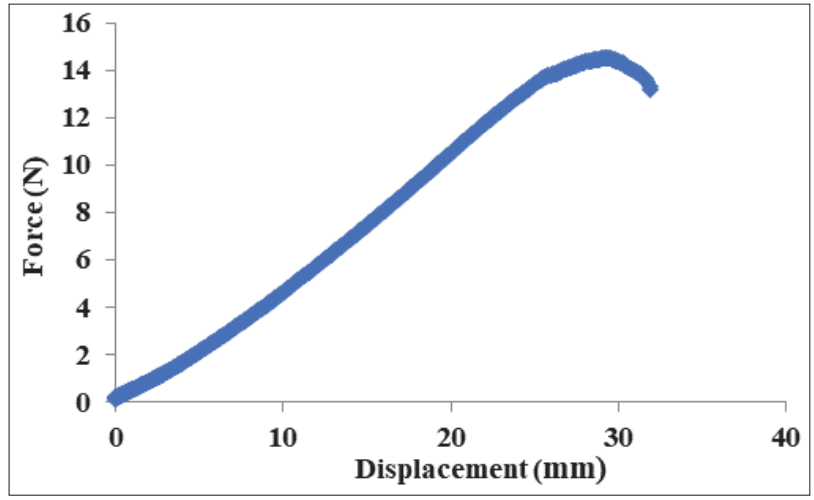

FIGURE 3. Force-deformation curve of the puncture test for an okra sample.

ment at $25^{\circ} \mathrm{C}$ with 50 to $60 \%$ relative humidity and in a refrigerator at $4 \pm 1^{\circ} \mathrm{C}$ with $95 \%$ relative humidity (Figure 1). The mechanical, physical, and rheological properties of the samples were evaluated every other day for 12 days.

\section{Firmness determination (puncher test)}

Puncher test was done using food testing device (Zwick/ Roell Model BT1_FR0.5TH.D14, made in Germany) equipped with a load cell (X Force Hp nominal Force: $500 \mathrm{~N}$ Capacity) in the laboratory of the Biosystems Group at Bu-Ali Sina University (Figure 2). Accordingly, the probe with $1.3 \mathrm{~mm}$ in diameter and $20 \mathrm{~mm} \mathrm{~min}^{-1}$ speed was used and in each replication, the diameter of each sample was applied simultaneously with probe penetration into the sample and the breaking force $\left(\mathrm{F}_{\text {brek }}\right)$, maximum force $\left(\mathrm{F}_{\max }\right)$, and modulus of elasticity $\left(E_{\text {mod }}\right)$ were determined directly from the results of the device's software. The test was done three times for each treatment (Figure 3).

\section{Measuring the weight loss percentage}

In the beginning of the tests and every other day during storage, the weight of the packages was measured and recorded using a digital scale with a precision of $0.001 \mathrm{~g}$. The results were calculated via Equation 1.

$$
w=\frac{M_{1}-M_{2}}{M_{1}} \times 100
$$

where $\mathrm{W}$ is the weight loss percentage, $\mathrm{M}_{1}$ is the initial weight of the samples, and $M_{2}$ the weight of the samples in certain days.

\section{Measuring the color of okra during storage}

In order to evaluate the color of okras during storage, the color model of $L^{*} a^{*} b^{*}$ and digital color meter (HP-200, made in China) with a precision of 0.01 color degree was used. For each treatment, three replications were randomly selected and for each experiment, it was first calibrated with white and black plates. The color properties included $L^{*}$ (brightness), $a^{*}$ (red-green), $b^{*}$ (yellow-blue), and $\Delta \mathrm{E}$ (color difference) were calculated by Equation 2 .

$$
\Delta \mathrm{E}=\sqrt{\Delta L^{2}+\Delta a^{2}+\Delta b^{2}}
$$

\section{Measuring atmosphere variations inside the package}

To evaluate the concentrations of $\mathrm{O}_{2}$ and $\mathrm{CO}_{2}$ gases, three packages of coated and uncoated treatments stored at 4 and $25^{\circ} \mathrm{C}$ were provided and their concentrations were measured every other day using a gas analyzer machine (Witt Gastechnik OXybaby 6i, made in Germany).

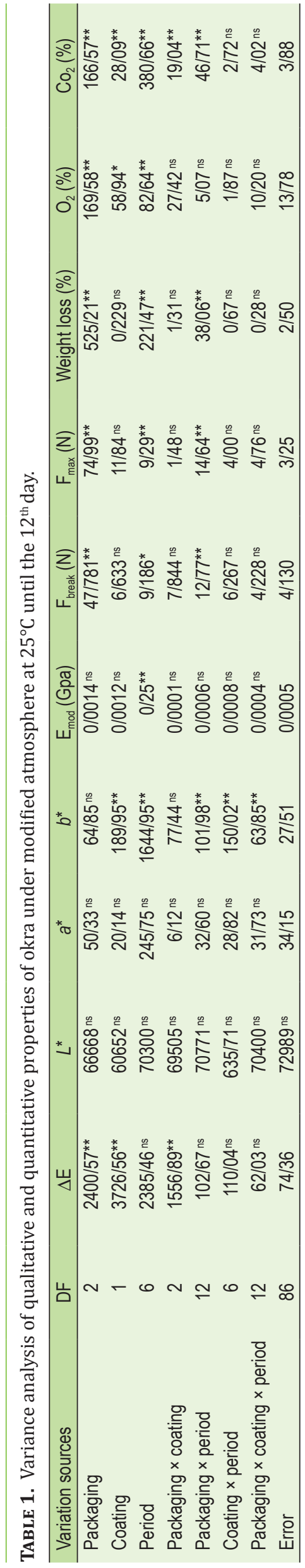




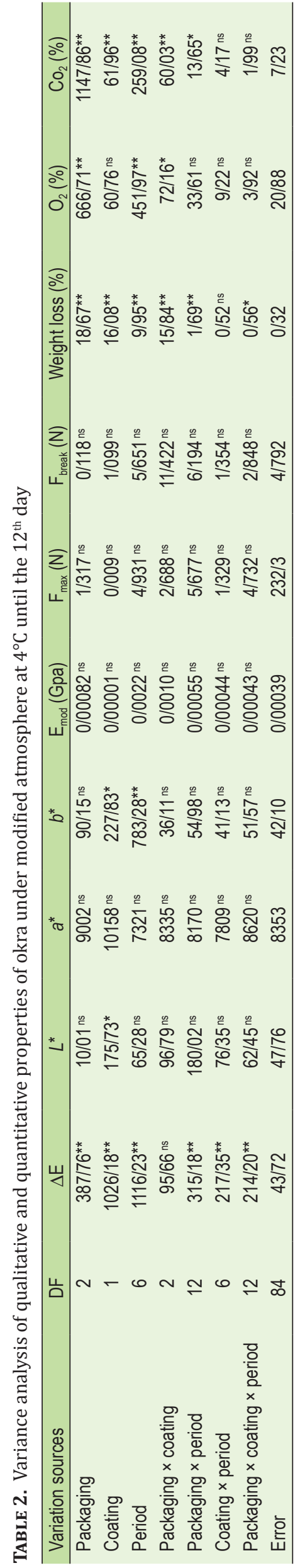

\section{Statistical analysis}

The present study was designed in the form of a completely randomized design in factorial with three replications. The data were normalized via Minitab14 software and analyzed by SAS software at the probability level $5 \%$ and $1 \%$. The averages were compared using the Tukey test.

\section{Results and discussion}

The packaging conditions and the properties of okras inside the packages stored at 4 and $25^{\circ} \mathrm{C}$ were evaluated. The evaluation was done until the $12^{\text {th }}$ day.

\section{Weight loss percentage}

The weight loss during the 12 days of storage has increased in all the treatments. The weight variations of treatment stored at $25^{\circ} \mathrm{C}$ are shown in Table 1 . As seen, the effect of packaging treatments, storage period, and interaction effect of packaging $\times$ period on final weight loss percentage was significant at $99 \%$ probability level $(\mathrm{P}<0.01)$, while chitosan coating had no significant effect on this product parameter during storage. Besides, the results of the variance analysis of the weight variation of the product during the storage at $4^{\circ} \mathrm{C}$ are shown in Table 2. As seen, there is a significant difference at the $1 \%$ probability level between the packaging, coating, storage, and their pair interactions. Tria interactions of packaging $\times$ coating $\times$ period were statistically significant at the $5 \%$ probability level. During storage, for all treatments, the trend of weight loss percentage was increased and the greatest weight loss was observed on the final day. Evaluating the interaction of packaging $\times$ period indicated that in $12^{\text {th }}$ day and at both temperatures of 4 and $25^{\circ} \mathrm{C}$, the nano polyethylene $(4.1 \%$ and $18.2 \%)$ and light polyethylene films $(1.2 \%$ and $5 \%$ ) had the maximum and minimum weight loss, respectively. As seen, the temperature of $4^{\circ} \mathrm{C}$ was effective in preventing the weight loss of samples and the minimum weight loss was observed. The minimum weight loss observed in light polyethylene film may be due to the less permeable packaging that creates a more proper atmosphere to maintain product weight inside the package, while in nano polyethylene film, the humidity loss and respiration rate is high due to its high

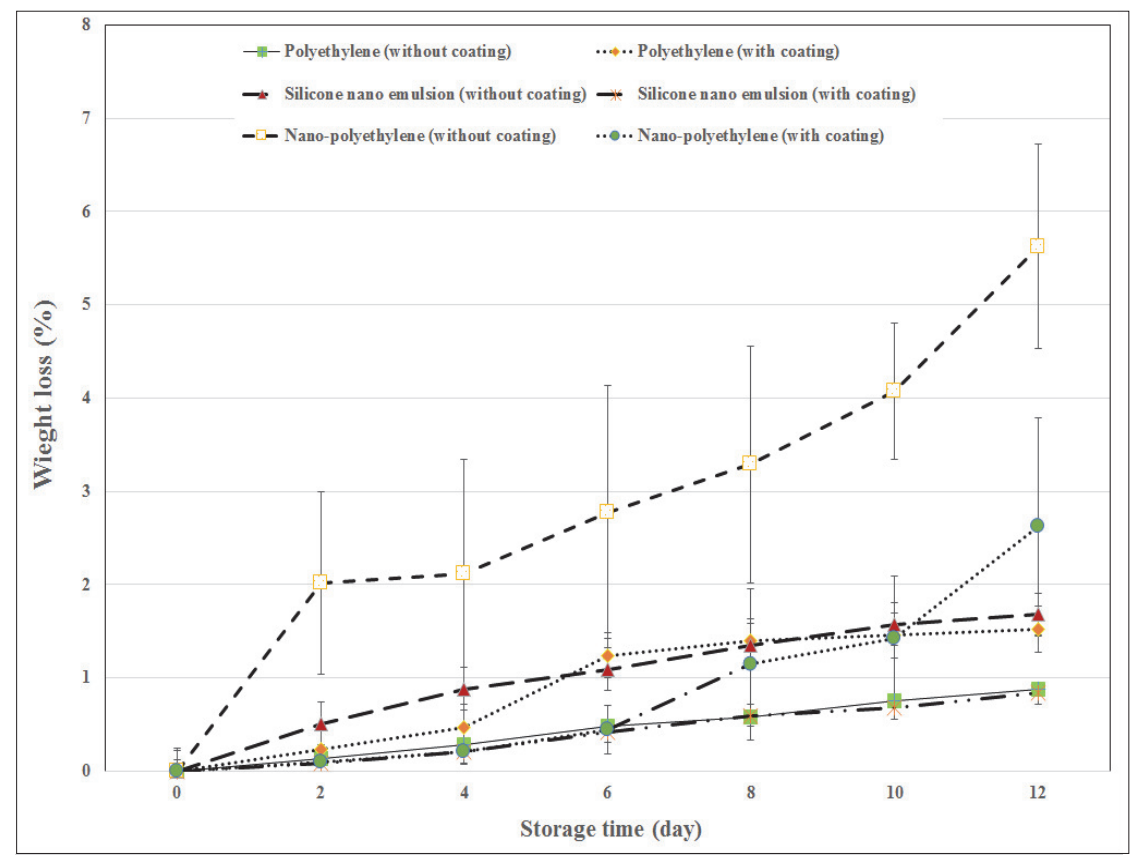

FIGURE 4. Effects of coating, and packaging film on changes of okra weight loss during storage at $4^{\circ} \mathrm{C}$. 
permeability, and as a result weight loss increases. Figure 4 shows the significant results of tria-interaction of packaging $\times$ coating $\times$ storage at $4^{\circ} \mathrm{C}$. In three types of packaging, the coated samples showed less weight loss compared to uncoated samples because of a reduction in dehydration of the product through edible chitosan coating. The lower level of weight loss in coated samples can be attributed to the creation of a protective layer by chitosan coating on the product that acts as a barrier and prevents severe changes during the storage time. In last day of storage, the minimum weight loss percentage $(0.8 \%)$ occurred in the samples with silicon nano emulsion coating because of a reduction in evaporation and dehydration, while the maximum weight loss (5.6\%) was observed in samples with nano polyethylene coating due to a high respiration rate. The positive and beneficial effect of chitosan on preserving water content of the fruit and weight loss in fruit such as strawberry (Hernandez-Munoz et al.,
2008), guava (Hong et al., 2012), and mushroom (Jiang et al., 2012) was reported. Besides, the weight loss at low temperature was reported by Finger et al. (2008) where the okras stored at $5-10^{\circ} \mathrm{C}$ showed less weight loss.

\section{The gas variations inside the package during the storage}

Considering Tables 1 and 2, the main effect of packaging and storage period on both carbon dioxide changes and oxygen changes were significant at the $99 \%$ probability level $(\mathrm{P}<0.01)$. In addition, the main effect of coating at a $1 \%$ level on $\mathrm{CO}_{2}$ (at 4 and $25^{\circ} \mathrm{C}$ ) and $\mathrm{O}_{2}$ (at $4^{\circ} \mathrm{C}$ ) changes were significant at $5 \%$ probability level. At the end of the storage period, data analysis showed that in all packing conditions at 4 and $25^{\circ} \mathrm{C}$, the amount of $\mathrm{CO}_{2}$ was decreased simultaneously with the respiration of the samples over time. Also, the maximum amount of $\mathrm{CO}_{2}(11.1 \%$ and $17.2 \%$, respectively)
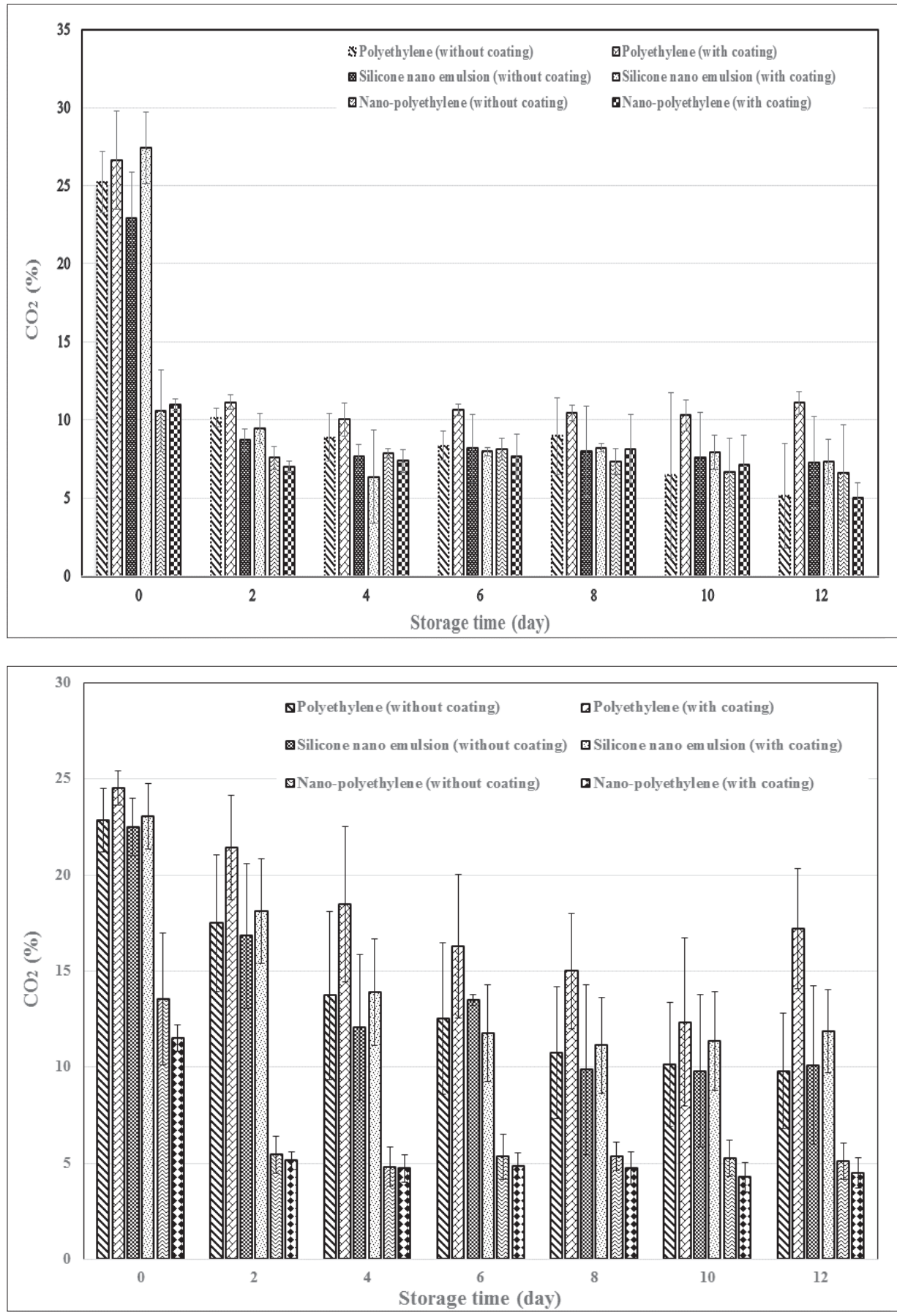

FIGURE 5. Effects of coating, and packaging film on changes of okra $\mathrm{CO}_{2}$ during storage at $25^{\circ} \mathrm{C}$.

FigURE 6. Effects of coating, and packaging film on changes of okra $\mathrm{CO}_{2}$ during storage at $4^{\circ} \mathrm{C}$. 
was observed in samples with polyethylene film coatings at both temperatures of 25 and $4^{\circ} \mathrm{C}$ (Figures 5 and 6). In addition, the minimum amount of oxygen was observed in the samples with polyethylene film coatings at 25 and $4^{\circ} \mathrm{C}$, which was $4.7 \%$ and $2.66 \%$, respectively; that indicates respiratory control in these conditions with the chitosan coating (Figures 7 and 8). The results of the comparison of the mean values of the main effects revealed that there was a significant difference between the three types of packaging so that the amount of $\mathrm{CO}_{2}$ and $\mathrm{O}_{2}$ aggregation in the polyethylene packages was higher than the nano emulsion packages due to the impermeability of polyethylene film against $\mathrm{CO}_{2}$ and
$\mathrm{O}_{2}$ exchange. Similar results have been reported by Gholami et al. (2017). During storage, respiration of the product will lead to a decrease in $\mathrm{O}_{2}$ and an increase in the concentration of $\mathrm{CO}_{2}$ inside the package. In the present study, during 12 days of storage, the amount of $\mathrm{O}_{2}$ was reduced from 20.5 to $8 \%$, which showed the decreasing trend of concentration, controlling the respiration, and reducing the aging activities and weight loss. Generally, the results of ANOVA (Tables 1 and 2) indicated the significant effect of type of packaging, coating, storage period, the pair interaction of packaging $\times$ period and packaging $\times$ coating on $\mathrm{CO}_{2}$ and $\mathrm{O}_{2}$ variations. It can be attributed to the high permeability of conventional
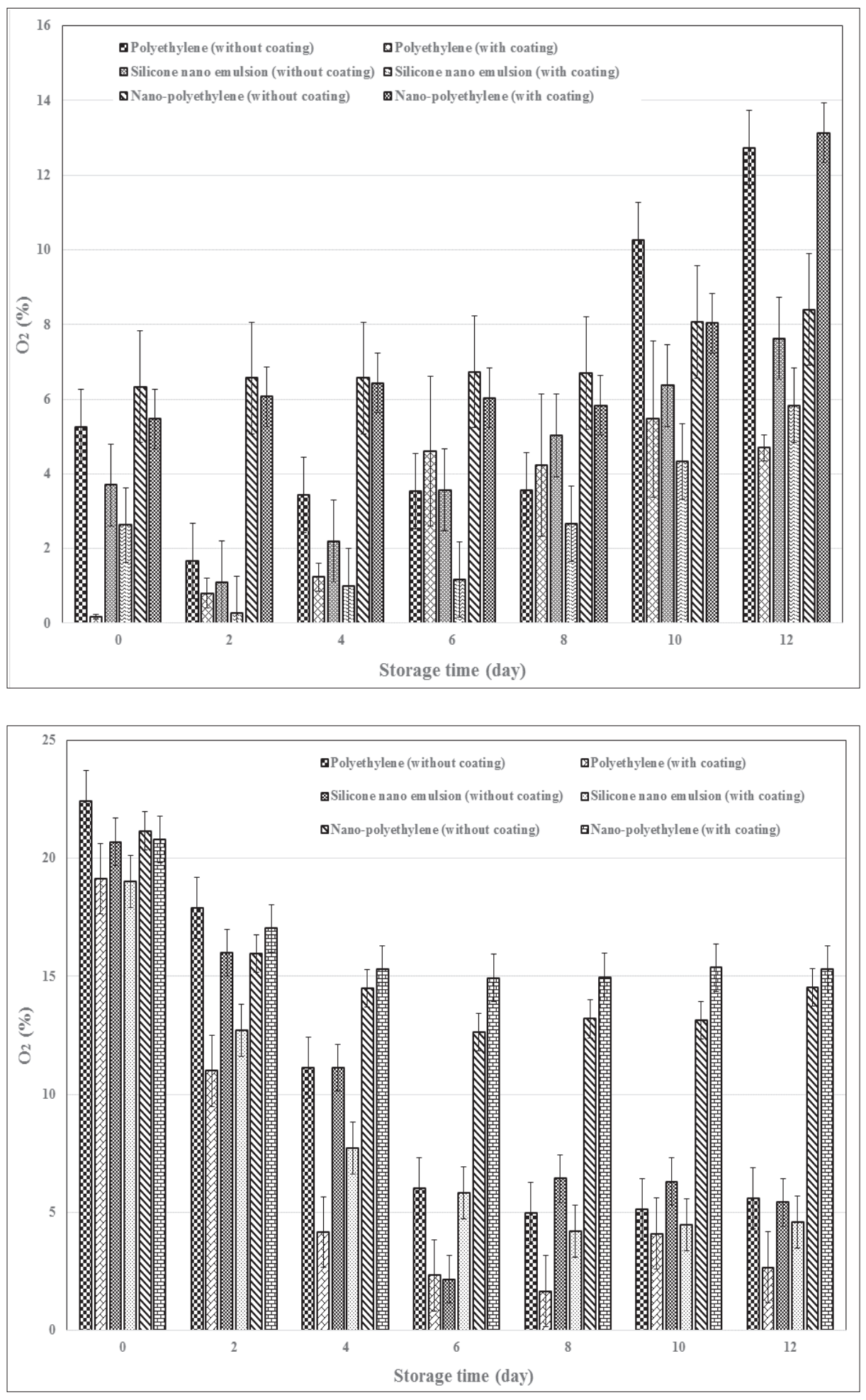

FIGURE 7. Effects of coating, and packaging film on changes of okra $\mathrm{O}_{2}$ during storage at $25^{\circ} \mathrm{C}$.
FigURE 8. Effects of coating, and packaging film on changes of okra $\mathrm{O}_{2}$ during storage at $4^{\circ} \mathrm{C}$. 
film to oxygen that, concurrent with the respiration of the product inside the package, causes gas exchange between the inside and outside gases. But the low permeability of the nanofilm packages, the transfer of gas from outside into the package is very low. The best gas composition at $4^{\circ} \mathrm{C}$ is with chitosan coating and in nanofilms, which increases the shelf life of the product.

\section{The change in the product tissue firmness during storage}

One of the main factors used in the determination of quality and shelf life of fruit and vegetables is the amount of reduction in product tissue firmness during storage (TanadaPalmu and Grosso, 2005). The reduction in the firmness of the products has a direct relationship with losing pectin compounds. The ANOVA of the firmness test (Puncher test) performed on treatments at $25^{\circ} \mathrm{C}$ is presented in Table 1 . As seen, the main effect of packaging on changes of $F_{\max }$ and $\mathrm{F}_{\text {break }}$ was significant at $1 \%$ probability level, while it was not significant on changes of $\mathrm{E}_{\text {mod. }}$. Moreover, the main effect of storage period on $\mathrm{F}_{\max }$ and $\mathrm{E}_{\bmod }$ was significant at $1 \%$, while its effect on $\mathrm{F}_{\max }$ was significant at $5 \%$ probability level. On the other hand, the interaction effect of the packaging $\times$ pe$\operatorname{riod}$ on $\mathrm{F}_{\max }$ and $\mathrm{F}_{\text {break }}$ was significant at $1 \%$ probability level. According to the results of the comparison of the mean values, on the $6^{\text {th }}$ day, the average amount of $F_{\max }$ and $F_{\text {break }}$ for silicon nano-emulsion films was 14.8 and $12.8 \mathrm{~N}$, respectively. It means that the firmness changes were influenced by the storage time, and by increasing storage time, the firmness gradually decreased. The reduction in silicon nano emulsion films was less than two other films at the end of the storage period compared to the beginning of the storage period (Figures 9 and 10). Generally, two parameters $\mathrm{F}_{\max }$ and $\mathrm{F}_{\text {break }}$ of nano-polyethylene film treatment were 7.8 and $6 \mathrm{~N}$, respectively, indicating that in this treatment, the tissue firmness of the samples was decreased. The ripeness of fruit during storage period occurs due to the tissue aging, sticking the cells, and pectin polymers dissolution in the tissue layers, thereby reducing the strength of the product (Nadim et al., 2015). Similar results were reported by Yurtlu and Erdoğan (2005) and Hassanpour et al. (2011). As shown in Table 2, the effect of independent variables of packaging, coating, period and their interactions on the changes of $F_{\max }, F_{\text {break, }}$ and $\mathrm{E}_{\text {mod }}$ were not significant at $4^{\circ} \mathrm{C}$. Therefore, it can be concluded that the temperature has a significant effect on the tissue response to mechanical damage, so that the insignificance of the parameters at $4^{\circ} \mathrm{C}$ indicated the preservation of tissue and product firmness due to control in the respiration and maintaining moisture in the samples as opposed to the effect with higher temperature.
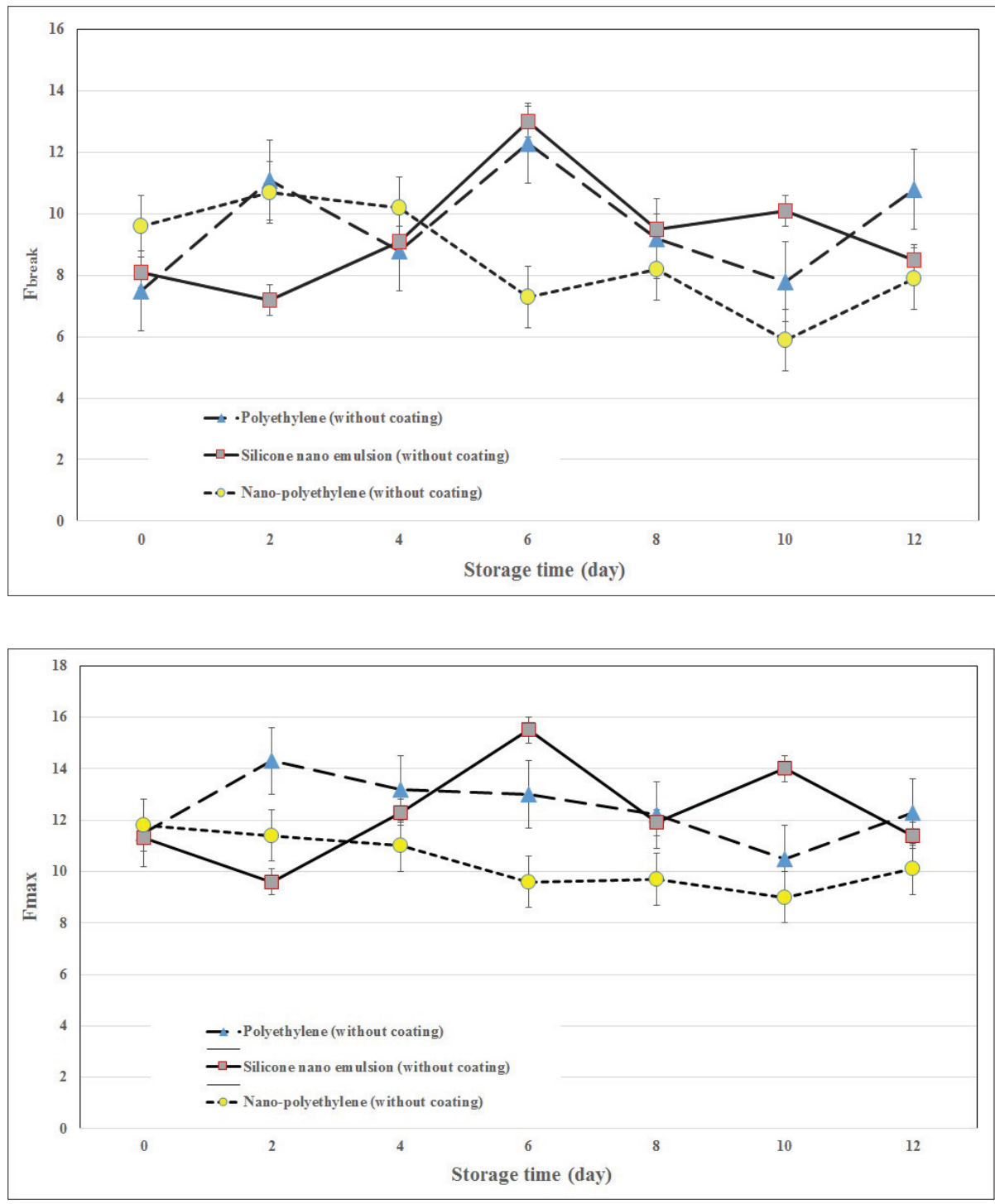

FIGURE 9. Effects of packaging film on changes of mechanical properties $\left(\mathrm{F}_{\text {break }}\right)$ during storage at $25^{\circ} \mathrm{C}$.
FIGURE 10. Effects of packaging film on changes of mechanical properties $\left(\mathrm{F}_{\max }\right)$ during storage at $25^{\circ} \mathrm{C}$. 


\section{The color indices and color difference during storage}

Color is one of the most important indices in the determination of maturity and quality of the fruit. According to Tables 1 and 2, the effect of the independent variables of packaging, coating, period, and their interactions on indices of $L^{*}$ and $a^{*}$ was not significant. The main effect of coating and period, pair interaction of packaging $\times$ period, the interaction of coating $\times$ period, and tria-interaction of packaging $\times$ coating $\times$ period on $b^{*}$ color index was significant at $5 \%$ probability level, while the main effect of coating on $b^{*}$ was not significant. Figure 11 illustrates the variations of $b^{*}$ from the beginning to the end of the storage period at $25^{\circ} \mathrm{C}$. As seen, by increasing the storage period, the amount of $b^{*}$ was significantly reduced in all treatments. The maximum amount of $b^{*}$ (57.3) was observed in the first day of storage in uncoated samples. During the storage, $b^{*}$ showed a decreasing trend (with the minimum value of 23 ) due to an increase in yellow color and product maturity. Nanoemulsion film-coated samples with $1.95 \%$ had the minimum changes compared to other treatments at the end of storage time. Coating with chitosan seems to be able to reduce the $b^{*}$ changes compared to uncoated samples. It should be noted that enzymatic browning which is one of the factors in fruit color change during storage that edible coatings can delay
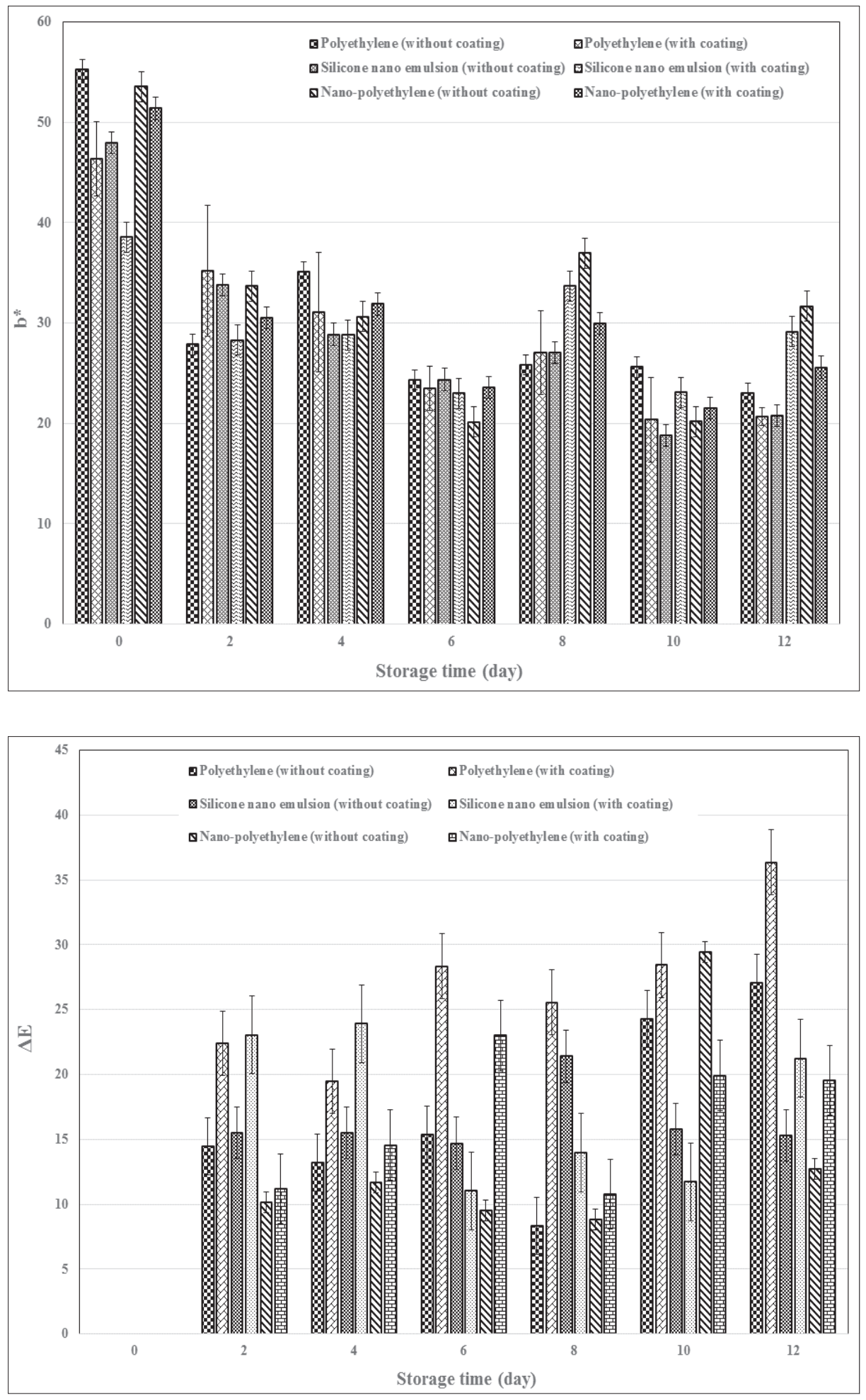

FIGURE 11. Effects of coating, and packaging film on changes of the $b^{*}$ index during storage at $25^{\circ} \mathrm{C}$.
FigurE 12. Effects of coating, and packaging film on changes of the $\Delta \mathrm{E}$ index during storage at $4^{\circ} \mathrm{C}$. 
the progress of this reaction by reducing the product's access to oxygen. The low brightness of the coated samples compared to uncoated ones can be due to chitosan coating. According to Table 2, the effect of coating and storage period on the $b^{*}$ index at $4^{\circ} \mathrm{C}$ was significant at $5 \%$ probability level $(\mathrm{P}<0.05)$ and similar to treatments at $25^{\circ} \mathrm{C}, b^{*}$ index was decreased from 41.3 (first day) to 24.1 (12 $12^{\text {th }}$ day) by progress in time. Table 2 presents the effect of independent variables of packaging, coating, storage period, and their interactions on color changes. As seen, although the main effect of coating was not significant, the main effects of packaging, coating, and interaction of coating $\times$ packaging on $\Delta \mathrm{E}$ of treatments at $25^{\circ} \mathrm{C}$ was significant. Comparing of the mean values of the interaction of packaging $\times$ coating showed that the maximum and minimum $\Delta \mathrm{E}$ was observed in uncoated samples of light polyethylene film (46.8) and silicon nano emulsion filmcoated samples (16). Table 2 shows the effect of packaging, coating, storage period, and their pair and tria-interactions at $4^{\circ} \mathrm{C}$ on $\Delta \mathrm{E}$. As seen, all main effects and interactions on $\Delta \mathrm{E}$ were significant at $5 \%$ probability level, except the interaction of coating $\times$ packaging. In Figure 12, the results and trends of changes of tria-interactions of packaging $\times$ coating $\times$ period on okra changes during storage at $4^{\circ} \mathrm{C}$ are shown. In all treatments, the amount of $\Delta \mathrm{E}$ showed significant changes during storage. On the $12^{\text {th }}$ day of storage, the maximum and minimum $\Delta \mathrm{E}$ respectively were observed in light polyethylene-coated samples (36.4\%) and uncoated samples of silicon nano-emulsion film coating (1.29\%). This showed that the nano film prevented the increase of $\Delta \mathrm{E}$, so that among the three types of packaging films, the minimum color changes was in uncoated samples and silicone nano-film. The results of the comparison of the mean values $\Delta \mathrm{E}$ factor showed that samples stored at $25^{\circ} \mathrm{C}$ had more color changes than samples stored at $4^{\circ} \mathrm{C}$. The increase in metabolic and enzymatic activities of the samples at this temperature and environmental conditions can be the reason for this increase. Babarinde and Fabunmi (2009) evaluated the effect of packaging films on the shelf life of okra and showed that the color changes were almost uniform until the third day of storage and after that $\Delta \mathrm{E}$ was increased. De Castro et al. (2007) reported the color changes in olive.

\section{Conclusion}

The results of the present research revealed that silicon nano emulsion film has a higher capability in preserving the qualitative and quantitative properties of okra compared to other studied films. The changes in parameters such as weight loss, firmness, oxygen, carbon dioxide and elasticity modulus at $4^{\circ} \mathrm{C}$ were less than $25^{\circ} \mathrm{C}$ during the storage period. The weight loss in chitosan-coated okra at $25^{\circ} \mathrm{C}$ and $4^{\circ} \mathrm{C}$ had the lowest amounts in films of light polyethylene film.

Between two studied temperatures, $4^{\circ} \mathrm{C}$ storage temperature had better performance in preserving qualitative and quantitative properties of the okra such as firmness compared to $25^{\circ} \mathrm{C}$. Controlled atmosphere increases okra's shelf life due to reduced respiration rate. The minimum of changes in color were observed in silicon nano emulsion film, which can be attributed to the favorable effect of nanoparticles. Chitosan edible coating delayed the product weight loss. The results of this investigation indicated that the employing of silicon nano emulsion film with chitosan coating under atmosphere conditions is useful for maintaining the quality properties of fruit and improving the shelf life, which is important in terms of marketability.

\section{References}

Al-Naamani, L., Dutta, J., and Dobretsov, S. (2018). Nanocomposite zinc oxide-chitosan coatings on polyethylene films for extending storage life of okra (Abelmoschus esculentus). Nanomaterials $8(7)$, 479-492. https://doi.org/10.3390/nano8070479.

Antala, D.K., Satasiya, R.M., Akabari, P.D., Bhuva, J.V., Gupta, R.A., and Chauhan, P.M. (2014). Effect of modified atmosphere packaging on shelf life of sapota fruit. Int. J. Agric. Sci. Technol. 2, 32-38. https:// doi.org/10.14355/ijast.2014.0301.05.

Babarinde, G.O., and Fabunmi, O.A. (2009). Effects of packaging materials and storage temperature on quality of fresh okra (Abelmoschus esculentus) fruit. Agric. Tropica et Subtropica 42(4), 151-156.

De Castro, A., Garcia, P., Romero, C., Brenes, M., and Garrido, A. (2007). Industrial implementation of black ripe olive storage under acid conditions. J. Food Engin. 80, 1206-1212. https://doi. org/10.1016/j.jfoodeng.2006.09.010.

Dimitrijevic, M., Karabasil, N., Boskovic, M., Teodorovic, V., Vasilev, D., Djordjevic, V., and Cobanovic, N. (2015). Safety aspects of nanotechnology applications in food packaging. Procedia Food Sci. 5, 57-60. https://doi.org/10.1016/j.profoo.2015.09.015.

Farinde, A.J., Owolarafe, O.K., and Ogungbemi, O.I. (2007). An overview of production, processing, marketing and utilisation of okra in Egbedore local government area of Osun State, Nigeria. Agric. Engin. Int. CIGR J. 4, 1-17.

Finger, F.L., Della-Justina, M.E., Casali, V.W.D., and Puiatti, M. (2008). Temperature and modified atmosphere affect the quality of okra. Sci. Agric. 65(4), 360-364. https://doi.org/10.1590/S010390162008000400006 .

Gemede, F., Ratta, N., Haki, D., Woldegiorgis, A.Z., and Beyene, F. (2015). Nutritional quality and health benefits of okra (Abelmoschus esculentus): A review. Int. J. Nutr. Food Sci. 4, 208-215. https://doi. org/10.11648/j.ijnfs.20150402.22.

Gholami, R., Ahmadi, E., and Farris, S. (2017). Shelf life extension of white mushrooms (Agaricus bisporus) by low temperatures conditioning, modified atmosphere, and nanocomposite packaging material. Food Pack. Shelf Life 14, 88-95. https://doi.org/10.1016/j. fpsl.2017.09.001.

Giacalone, G., and Chiabrando, V. (2013). Modified atmosphere packaging of sweet cherries with biodegradable films. Int. Food Res. J. 20(3), 1263-1268.

Hassan, B., Chatha, S.A.S., Hussain, A.I., Zia, K.M., and Akhtar, N. (2018). Recent advances on polysaccharides, lipids and protein based edible films and coatings: A review. Int. J. Biol. Macromol. 109, 1095-1107. https://doi.org/10.1016/j.ijbiomac.2017.11.097.

Hassanpour, A., Modarres Motlagh, A., Esmaili, M., and Rahmani Didar, A. (2011). Changes in the mechanical properties of white seedless grapes during different maturity stages. J. Food Res. 21, 343-355 (in Farsi).

Hernandez-Munoz, P., Almenar, E., Valle, V.D., Velez, D., and Gavara, R. (2008). Effect of chitosan coating combined with postharvest calcium treatment on strawberry (Fragaria $\times$ ananassa) quality during refrigerated storage. Food Chem. 110, 428-435. https://doi. org/10.1016/j.foodchem.2008.02.020.

Hong, K., Xie, J., Zhang, L., Sun, D., and Gong, D. (2012). Effects of chitosan coating on postharvest life and quality of guava (Psidium guajava L.) fruit during cold storage. Sci. Hortic. 144, 172-178. https://doi.org/10.1016/j.scienta.2012.07.002.

Hosain, M.M., Jannat, R., Islam, M.M., and Sarker, M.K.U. (2010). Processing and preservation of okra pickle. Progr. Agric. 21(1-2), 215-222. https://doi.org/10.3329/pa.v21i1-2.16777. 
Janick, J. (1993). Horticultural Reviews, Vol. 15 (New York: John Wiley \& Sons). https://doi.org/10.1002/9780470650547.

Jiang, T., Feng, L., and Wang, Y. (2013). Effect of alginate/nano-Ag coating on microbial and physicochemical characteristics of shiitake mushroom (Lentinus edodes) during cold storage. Food Chem. 141(2), 954-960. https://doi.org/10.1016/j.foodchem.2013.03.093.

Jiang, T.J., Feng, L.F., and Li, J.R. (2012). Changes in microbial and postharvest quality of shiitake mushroom (Lentinus edodes) treated with chitosan-glucose complex coating under cold storage. Food Chem. 131, 780-786. https://doi.org/10.1016/j. foodchem.2011.08.087.

Leceta, I., Molinaro, S., Guerrero, P., Kerry, J.P., and De la Caba, K (2015). Quality attributes of map packaged ready-to-eat baby carrots by using chitosan-based coatings. Postharvest Biol. Technol. 100,142-150. https://doi.org/10.1016/j.postharvbio.2014.09.022.

Li, X., Yun, J., Fan, X., Xing, Y., and Tang, Y. (2011). Effect of 1-methylcyclopropene and modified atmosphere packaging on chilling injury and antioxidative defensive mechanism of sweet pepper. African J. Biotechnol. 10(34), 6581-6589.

Liu, J., Liu, S.H., Zhang, X., Kan, J., and Jin, C.H. (2019). Effect of gallic acid grafted chitosan film packaging on the postharvest quality of white button mushroom (Agaricus bisporus). Postharvest Biol. Technol. 147, 39-47. https://doi.org/10.1016/j.postharvbio.2018.09.004.

Manjunatha, M., and Anurag, R.K. (2014). Effect of modified atmosphere packaging and storage conditions on quality characteristics of cucumber. J. Food Sci. Technol. 51(11), 3470-3475. https://doi.org/10.1007/s13197-012-0840-7.

Nadim, Z., Ahmadi, E., Sarikhani, H., and Amiri Chayjan, R. (2015). Effect of methyl-cellulose-based edible coating on strawberry fruit's quality maintenance during storage. J. Food Process. Preserv. 39, 80-90. https://doi.org/10.1111/jfpp.12227.

Petropoulos, S., Fernandes, Â., Barros, L., and Ferreira, I.C. (2018). Chemical composition, nutritional value and antioxidant properties of Mediterranean okra genotypes in relation to harvest stage. Food Chem. 242, 466-474. https://doi.org/10.1016/j. foodchem.2017.09.082.

Rai, D.R., Oberoi, H.S., and Baboo, B. (2002). Modified atmosphere packaging and its effect on quality and shelf life of fruits and vegetables - An overview. J. Food Sci. Technol. 39(3), 199-207.

Rossi, M., Passeri, D., Sinibaldi, A., Angjellari, M., Tamburri, E., Sorbo, A., and Dini, L. (2017). Nanotechnology for food packaging and food quality assessment. Adv. Food Nutr. Res. 82, 149-204. https://doi. org/10.1016/bs.afnr.2017.01.002.

Sandhya (2010). Modified atmosphere packaging of fresh produce: Current status and future needs. LWT - Food Sci. Technol. 43, 381392. https://doi.org/10.1016/j.lwt.2009.05.018.

Sivankalyani, V., Feygenberg, O., Maorer, D., Zaaroor, M., Fallik, E., and Alkan, N. (2015). Combined treatments reduce chilling injury and maintain fruit quality in Avocado fruit during cold quarantine. PLoS ONE 10(10), e0140522. https://doi.org/10.1371/journal. pone.0140522.

Taghizadeh, M., Gowen, A., Ward, P., and O'Donnell, C.P. (2010). Use of hyperspectral imaging for evaluation of the shelf-life of fresh whitebutton mushrooms (Agaricus bisporus) stored in different packaging films. Innov. Food Sci. Emerg. Technol. 11, 423-431. https://doi.org/10.1016/j.ifset.2010.01.016.

Tanada-Palmu, P.S., and Grosso, C.R.F. (2005). Effect of edible wheat gluten-based films and coatings on refrigerated strawberry (Fragaria ananassa) quality. Postharvest Biol. Technol. 36, 199-208. https://doi.org/10.1016/j.postharvbio.2004.12.003.
Uysal Unalan, I., Cerri, G., Marcuzzo, E., Cozzolino, C.A., and Farris, S. (2014). Nano-composite films and coatings using inorganic nanobuilding blocks (NBB): Current applications and future opportunities in the food packaging sector. RSC Advances 4, 2939329428. https://doi.org/10.1039/C4RA01778A.

Viswanath, M., Srinivasulu, B., Swarajya Lakshmi, K., and Gopal, M. (2018). Effect of edible coatings and storage temperatures on maintenance of aril quality and microbial population of pomegranate cv. Bhagwa packed in clamshells. Int. J. Current Microbiol. Appl. Sci. 7(1), 2244-2252. https://doi.org/10.20546/ijcmas.2018.701.271.

Wyser, Y., Adams, M., Avella, M., Carlander, D., Garcia, L., Pieper, G., and Weiss, J. (2016). Outlook and challenges of nanotechnologies for food packaging. Packaging Technol. Sci. 29(12), 615-648. https:// doi.org/10.1002/pts.2221

Yurtlu, Y.B., and Erdoğan, D. (2005). Effect of storage time on some mechanical properties and bruise susceptibility of pears and apples. Turkish J. Agric. Forestry 29(6), 469-482.

Received: Jan. 30, 2020

Accepted: Dec. 16, 2020

Addresses of authors:

Azadeh Heydarian ${ }^{1}$, Ebrahim Ahmadi ${ }^{1, *}$ and Farshad Dashti ${ }^{2}$ ${ }^{1}$ Department of Biosystems Engineering, Faculty of Agriculture, Bu-Ali Sina University, Hamedan, Iran ${ }^{2}$ Department of Horticultural Science, Faculty of Agriculture, Bu-Ali Sina University, Hamedan, Iran

* Corresponding author; E-mail: eahmadi@basu.ac.ir 